\title{
THE UNCERTAINTY OF HARDNESS MEASUREMENTS RELATED TO THE MEASUREMENT METHOD, SURFACE PREPARATION AND RANGE OF THE MEASUREMENTS
}

\author{
ANALIZA MERILNE NEGOTOVOSTI IN DOLOČITEV \\ METODOLOGIJE IZVAJANJ MERITEV TRDOT
}

\author{
Agnieszka Zuzanna Guštin ${ }^{1 *}$, Borut Žužek ${ }^{1}$, Bojan Podgornik ${ }^{1}$, \\ Varužan Kevorkijan ${ }^{2}$ \\ ${ }^{1}$ Institute of Metals and Technology, Lepi pot 11, 1000 Ljubljana, Slovenia \\ 2Impol Aluminium Industry, Partizanska 38, 2310 Slovenska Bistrica, Slovenia \\ Prejem rokopisa - received: 2019-09-12; sprejem za objavo - accepted for publication: 2019-10-20
}

doi:10.17222/mit.2019.098

\begin{abstract}
The main purpose of this paper is to present the changes in hardness-measurement uncertainty depending on the measurement method, the number of measurements and the surface preparation. The experiments were executed on the $\mathrm{AlCuMgPb}$ aluminium alloy series $2 \mathrm{xxx}$, manufactured from one batch of homogenous material. The measurements were performed on milled and polished surfaces using different hardness-test methods: Brinell, Vickers and Rockwell. The goal of this study was to select the optimum hardness test method together with the surface preparation that provide the best results in terms of measurement uncertainty. Finally, the results including the effect of the number of performed measurements for different surface preparations were presented. The statistical deviation in the hardness-measurement results showed a lowest scatter of measured results for the Rockwell method and the largest for the Brinell test. It was also concluded that the repeatability increased when surface of the sample was polished, simultaneously only three measurements were needed, using the Brinell and Rockwell methods, to achieve the minimum required error parameters.
\end{abstract}

Keywords: hardness measurements, surface preparation, measurement uncertainty, aluminum

Namen raziskave je bil analizirati spremembe vrednosti merilne negotovosti pri meritvah trdote glede na izbrano metodo merjenja trdote, število ponovitev ter pripravo površine. Preizkusi so bili izvedeni na aluminijevi zlitini $\mathrm{AlCuMgPb}$ serije $2 \mathrm{xxx}$, iz ene serije homogenega materiala. Meritve trdote $\mathrm{z}$ uporabo različnih metod merjenja (Brinell, Vickers in Rockwell) so bile izvedene na poliranih in rezkanih površinah vzorcev. Cilj študije je bil identificirati optimalno metodo merjenja trdote skupaj $z$ ustrezno pripravo površine, ki zagotavlja najboljše rezultate v smislu merilne negotovosti. Predstavljeni so rezultati, ki vključujejo vpliv števila opravljenih meritev za različno pripravo površine. Nihanje rezultatov merjenja trdote je pokazalo najmanjši raztros v primeru meritev izvedenih po Rockwellu, največje nihanje pa je bilo pri merjenju trdote po Brinellu. Ugotovili smo, da se je pri polirani površini vzorca povečala ponovljivost meritev, obenem pa so bile potrebne pri uporabi Brinellove in Rockwellove metode le 3 ponovitve za doseganje minimalnih parametrov odstopanja.

Ključne besede: meritve trdot, rezkana in polirana površina, merilna negotovost, aluminij

\section{INTRODUCTION}

Hardness tests are one of the fastest and the least expensive methods for defining the mechanical properties of materials. ${ }^{1}$ Therefore, hardness testing is often used for material assessment, during the research and development of a material, as well as in the quality control of the production process. The hardness method selected and used should be determined by the microstructure, i.e., the homogeneity of the material, as well as the type of material, the size of the part and its condition. There are three main hardness-measurement methods used for metallic materials, each with their own set of benefits and requirements, defined by appropriate standards, which also explain the procedure and application of the hardness test in details. The three most common indentation hardness testes are: Brinell, Vickers and Rockwell.

*Corresponding author's e-mail:

agnieszka.gustin@imt.si (Agnieszka Zuzanna Guštin)
The Vickers hardness (HV) is calculated by measuring the size of an indent (diagonal lengths) left in the sample material by pressing a diamond pyramid indenter with a given load. The diagonals of the indent are measured optically in order to determine the hardness, using a table or formula. The Rockwell test (HR) is calculated by measuring the depth of an indent after an indenter has been forced into the specimen material at a given load. The Brinell method $(\mathrm{HB})$ requires optical reading of the diameter of a hard ball indentation and then using a chart to convert the average measurement to the Brinell hardness value. The decision for the selection of the type of the hardness test is significantly affected by the dimension of the specimen as well as its hardness. For softer metals and alloys the most appropriate and accurate hardness method is the Brinell method. Implementation of this method is possible on the specimens with a relatively smooth surface. A very smooth polished surface is necessary when the Vickers methods is used in order to avoid an excessive measurement error. ${ }^{2}$ Further- 
more, surface roughness is extremely important in instrumented indentation hardness testing, because the mechanical properties of the tested material are calculated on the assumption that the sample surface if flat. 3,4

As mentioned, the surface condition influences both the measured hardness value as well as the measurement uncertainty, which is especially important in the industrial environment, requiring high repeatability. The characteristics of the empirically developed hardness tests make it difficult to determine the measurement uncertainty using methods based on mathematical models. ${ }^{5}$ However, the European Association of National Metrology Institutes has developed guidelines ${ }^{6}$ that help in estimating the uncertainty in hardness measurements. It lists four main groups of influencing parameters that affect the uncertainty of hardness measurements, with the test piece non-homogeneity and its surface quality being number one. This is followed by the hardness testing machine, environment and operator. The surface quality of the test piece may considerably influence the results of hardness measurements, with a rougher surface requiring a greater force and a larger indenter to produce a larger indentation. ${ }^{6}$ Furthermore, in general, the influence of roughness and material non-homogeneity can be improved as the number of hardness measurements is increased. ${ }^{5}$

This study is focused on the selection of the most appropriate hardness method together with a surface preparation that enables the best results in terms of measurement uncertainty when measuring the hardness of Al alloys. Finally, the object is to study the differences in the hardness results when the measurements are performed on milled and polished specimens. The statistical deviation in hardness measurement results is then briefly discussed in order to verify the reliability of the hardness measurements.

\section{EXPERIMENTAL PART}

The main goal of this research is to present a statistical analysis of the hardness measurements performed by three different hardness test methods: Brinell, Vickers and Rockwell. For an easier comparison of the obtained results, all the measurements were performed on the same material and specimens. The used test material, applied methods and equipment are described in the sections below.

\subsection{Test material}

The hardness tests were performed on aluminium alloy series 2xxx ( $\mathrm{AlCuMgPb})$ in $\mathrm{T} 6$ condition, manufactured from one batch of homogenous material. Test specimens in the form of square blocks $(10 \times 10 \times 100) \mathrm{mm}$ were cut from extruded rods of a $20 \mathrm{~mm}$ diameter and surface finished by using standard milling and polishing conditions (Figure 1). Due to the statistical relevance of the results, ten measurements were carried out on each of the five successive specimens in the milled and polished state.

\subsection{Test methods and equipment}

The hardness measurements were performed by using three hardness-test methods: Brinell (HBW), Vickers (HV) and Rockwell (HRBW) according to the latest ISO standards, which requires that the test shall be carried out on a surface that is smooth and even, free from oxide scale, lubricants and foreign material. The Brinell hardness test was performed according to the SIST EN ISO 6506-1:2014 standard $^{7}$ using an Innovates NEXUS 7501 testing machine with a 2.5 -mm-diameter ball and a load of $62.5 \mathrm{kgf}$ (HBW2.5/62.5). The Vickers hardness test was performed according to the SIST EN ISO 6507-1:2018 standard $^{8}$ on a Wilson Instrument Tukon 2100B testing machine with a load of $10 \mathrm{kgf}$ (HV10). The Rockwell hardness test (HRBW) was performed according to the SIST EN ISO 6508-1:2016 standard ${ }^{9}$ using a Wilson Instruments B2000 testing machine, a load of $100 \mathrm{kgf}$ and a $1.587 \mathrm{~mm}$ diameter ball.

\subsection{Test parameters}

For each group of measurements the statistical analysis was performed, which includes calculations of the following parameters: ${ }^{10}$

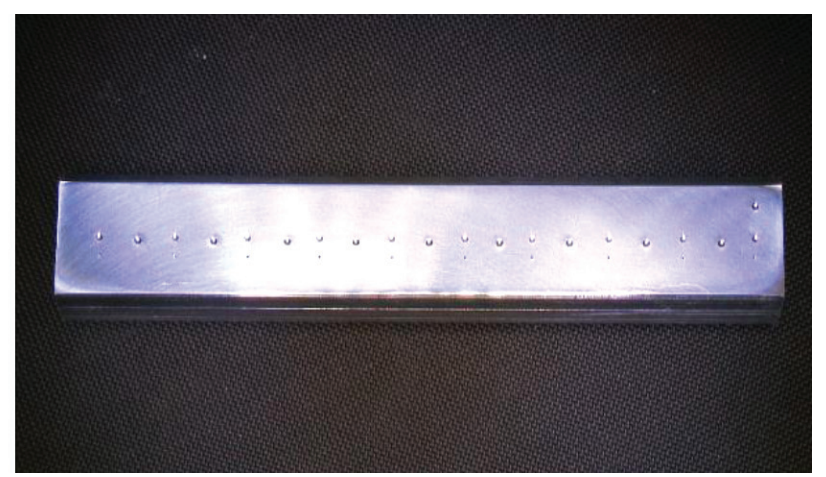

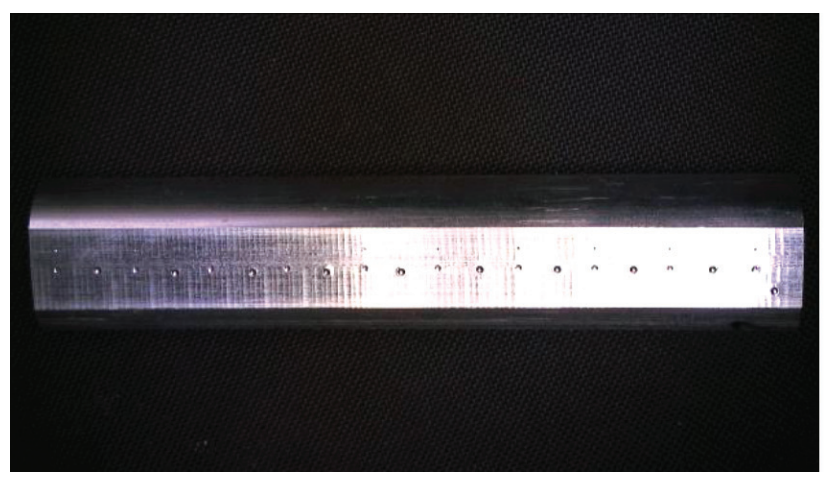

Figure 1: Examples of tested specimens with milled (left) and polished (right) surfaces 


\section{A. Z. GUŠTIN et al.: THE UNCERTAINTY OF HARDNESS MEASUREMENTS RELATED TO THE MEASUREMENT METHOD ...}

The average value:

$$
\bar{x}=\frac{1}{n} \sum_{i=1}^{n} x_{i}
$$

where $n$ represents the number of measurements and $x_{i}$ the individual measurement.

The standard deviation $s$ :

$$
\begin{aligned}
& s=\sqrt{\frac{\sum_{i=1}^{n}\left(x_{i}-\bar{x}\right)^{2}}{n-1}} \\
& s_{\%}=\frac{s}{\bar{x}} \times 100 \%
\end{aligned}
$$

The standard measurement uncertainty $u$ :

$$
\begin{gathered}
u=\frac{s}{\sqrt{n}} \\
u_{\%}=\frac{u}{\bar{x}} \times 100 \%
\end{gathered}
$$

And the repeatability of measurements $b$ :

$$
b=\frac{x_{\max }-x_{\min }}{\bar{x}}
$$

$x_{\max }$ and $x_{\min }$ represent the minimum and maximum measured values from the set of measurements.

\section{RESULTS}

This section presents the results of the statistical calculations according to the measurements performed on one sample and then for all the tested samples. For the discussion we chose one sample with calculated statistical parameters that were the closest to the average values.

\subsection{Brinell test results}

Measurement results from the milled and polished surface according to the Brinell test are summarized in Table 1 and graphically presented in Figure 2 and Figure 3, respectively.

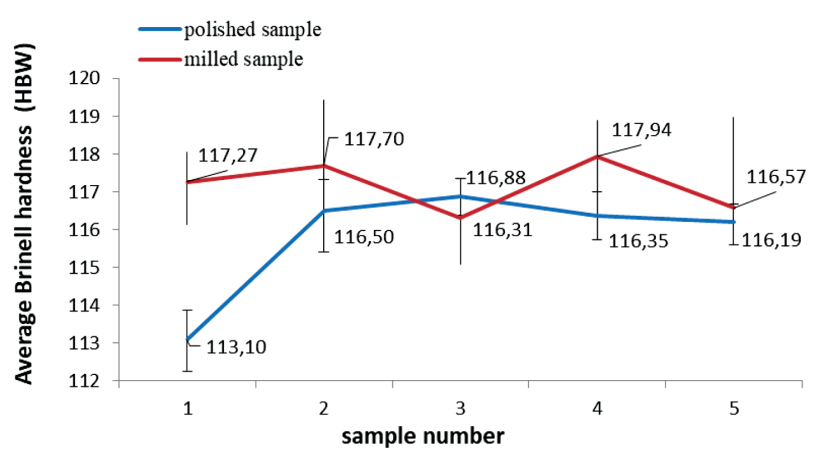

Figure 2: The average Brinell hardness results obtained for milled and polished specimens

Note: The min and max values of error bars are depicted with a cap for polished and with no cap for milled samples for all diagrams.
For each of five samples in the milled state (1-M to $5-\mathrm{M})$ the average measured hardness value is between 116.3 and 117.9 HBW. The standard deviation $(s)$ varies from $0.48 \%$ to $0.80 \%$, the estimated standard measurement uncertainty $(u)$ is between $0.15 \%$ and $0.25 \%$ and the repeatability $(b)$ is between $1.63 \%$ and $2.76 \%$.

If all 50 individual measurements are taken into the account, the average hardness value is $117.2 \mathrm{HBW}$, the standard deviation $(s)$ increases to $0.83 \%$ and the repeatability $(b)$ to $3.70 \%$, while the estimated standard measurement uncertainty $(u)$ decreases to $0.12 \%$ (Table 1).

In the case of measurements performed on a polished surface (1-P to 5-P) the mean hardness values are lower, between 113.1 and $116.9 \mathrm{HBW}$. Lower are also the standard deviation $(s)$, from $0.25 \%$ to $0.57 \%$, the estimated standard measurement uncertainty $(u)$, between $0.10 \%$ and $0.18 \%$ and the repeatability $(b)$, from $0.85 \%$ to $1.63 \%$.

Again, if all 50 individual measurements are taken into account the standard deviation $(s)$ decreases to $1.26 \%$ and the estimated standard measurement uncertainty $(u)$ to $0.18 \%$, while the repeatability increases to $4.42 \%$. As can be seen from Figure 2, the hardness measurements performed on the polished Al surface are lower by 1-2\% compared to the milled one. Furthermore, for this single sample the standard deviation and repeatability are reduced by about $40 \%$, when switching from milled to polished surface. The standard deviation was reduced from $0.64 \%$ to $0.38 \%$, the estimated measurement uncertainty from $0.20 \%$ to $0.12 \%$ and the repeatability from $1.92 \%$ to $1.09 \%$ (Figure 3). On the other hand, in the case of a polished surface, non-homo-

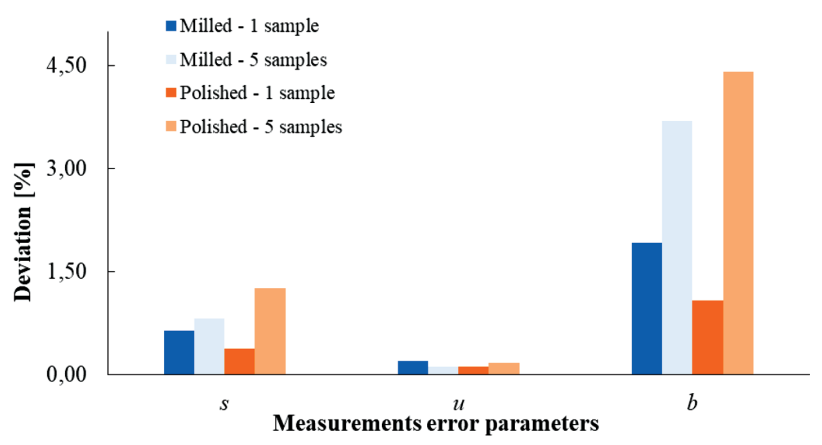

Figure 3: Influence of surface preparation on measurement error for Brinell hardness test (Table 1)

Table 1: Statistical calculations according to the measurements performed on five milled and polished specimens using the Brinell test

\begin{tabular}{|l|c|c|c|c|}
\hline $\begin{array}{c}\text { Deviation } \\
\text { calculations (\%) }\end{array}$ & $\bar{x}$ & $s$ & $u$ & $b$ \\
\hline \multicolumn{5}{|c|}{ MILLED SURFACE } \\
\hline average per sample & $117.2 \mathrm{HBW}$ & 0.64 & 0.20 & 1.92 \\
\hline all measurements & $117.2 \mathrm{HBW}$ & 0.83 & 0.12 & 3.70 \\
\hline \multicolumn{5}{|c|}{ POLISHED SURFACE } \\
\hline average per sample & $115.8 \mathrm{HBW}$ & 0.38 & 0.12 & 1.09 \\
\hline all measurements & $115.8 \mathrm{HBW}$ & 1.26 & 0.18 & 4.42 \\
\hline
\end{tabular}


geneity of the material becomes more pronounced, resulting in a more than doubled standard deviation $(1.26 \%)$, almost no changes of the estimated standard measurement uncertainty $(0.16 \%)$ and the repeatability $(4.42 \%)$, when measurements over all five samples are taken into the account (Figure 3).

\subsection{Vickers test results}

The results of the Vickers hardness measurements are summarized in Table $\mathbf{2}$ and graphically presented in Figure 4 and Figure 5.

In the case of measurements performed on a milled surface, the average hardness value is between 119.9 and 123.5 HV10 (Figure 4), the standard deviation $(s)$ is between $1.17 \%$ and $2.76 \%$, the estimated measurement uncertainty $(u)$ between $0.44 \%$ and $0.96 \%$ and the repeatability $(b)$ between $3.48 \%$ and $7.97 \%$. Results show that in the case of the Vickers method the measurement uncertainty for milled surfaces is considerably greater (around three times) than in the case of the Brinell hardness measurements.

If all the individual measurements are considered, the average hardness value is $122.2 \mathrm{HV} 10$, no changes of standard deviation $(s) 2.35 \%$, while the repeatability $(b)$ reaches $9.0 \%$, the estimated measurement uncertainty (u) decreases to $0.33 \%$ (Table 2).

In the case of measurements performed on polished surfaces, again the mean measured hardness values are lower, between 118.2 and $122.5 \mathrm{HV} 10$, as shown in Figure 4. Furthermore, also the measurement error has been reduced by more than $40 \%$. However, it still remains considerably larger than for the Brinell method. The standard deviation is between $0.38 \%$ and $0.80 \%$, the estimated measurement uncertainty is between $0.12 \%$ and $0.25 \%$, and the repeatability is between $1.24 \%$ and $2.55 \%$.

If all 50 individual measurements are taken into the account, the standard deviation decreases to $1.31 \%$, the estimated uncertainty to $0.29 \%$ and the repeatability to $5.13 \%$ (Table 2).

According to the measurements performed on a single sample switching from a milled to a polished sur-

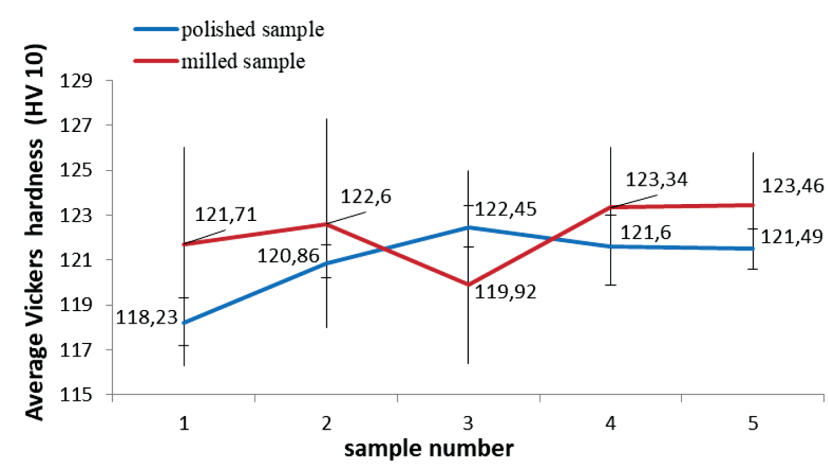

Figure 4: Average Vickers hardness results obtained for milled and polished specimens face, the results in the standard deviation, the estimated measurement uncertainty, and the repeatability are reduced by 3-4 times (Figure 5). Again, in the case of measurements performed on a polished surface, the effect of inhomogeneity of the material is observed, which reflects the same trend as in the case of the Brinell test. The standard deviation decreases from $2.35 \%$ to $1.31 \%$, the estimated measurement uncertainty from $0.33 \%$ to $0.29 \%$, and the repeatability from $9.0 \%$ to $5.13 \%$ when taking all the measurements into account (Figure 5).

\subsection{Rockwell test results}

The results of the Rockwell hardness testing performed on milled and polished specimens are summarized in Table $\mathbf{3}$ and graphically presented in Figure 6 and Figure 7.

In the case of the milled surface, the average measured value is between 67.8 and $68.5 \mathrm{HRB}$, see Figure 6, the standard deviation $(s)$ between $0.25 \%$ and $0.91 \%$, the estimated measurement uncertainty $(u)$ between $0.07 \%$ and $0.19 \%$ and the repeatability $(b)$ between $0.74 \%$ and $2.51 \%$. This is very comparable to the results of the Brinell hardness measurements.

If all 50 individual measurements are taken into account, the average hardness value is $68.1 \mathrm{HRB}$, the standard deviation $(s)$ increase to $0.74 \%$ and the repeatability $(b)$ to $3.38 \%$, while the estimated measurement uncertainty $(u)$ decreases to $0.10 \%$ (Table 3).

In the case of measurements performed on a polished surface the measurement error has improved compared to the milled surface. When performing a measurement

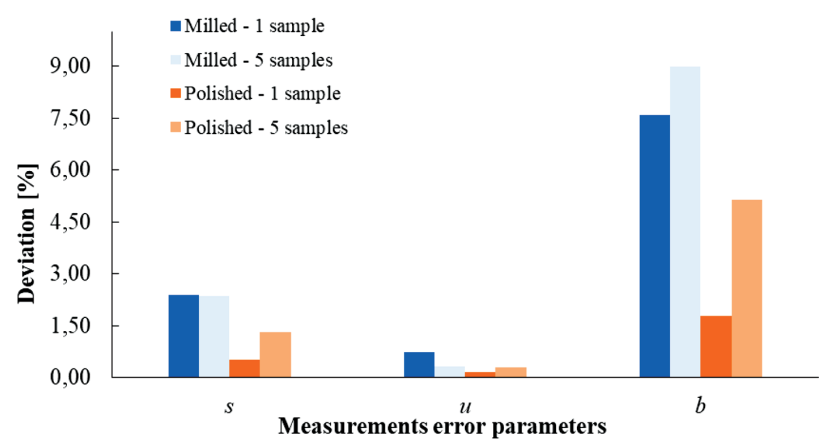

Figure 5: Influence of surface preparation on the measurement error for the Vickers test method (Table 2)

Table 2: Statistical calculations according to the measurements performed on five milled and polished specimens using the Vickers test

\begin{tabular}{|l|c|c|c|c|}
\hline $\begin{array}{c}\text { Deviation } \\
\text { calculations (\%) }\end{array}$ & $\bar{x}$ & $s$ & $u$ & $b$ \\
\hline \multicolumn{5}{|c|}{ MILLED SURFACE } \\
\hline average per sample & $122.2 \mathrm{HV}$ & 2.39 & 0.75 & 7.59 \\
\hline all measurements & $122.2 \mathrm{HV}$ & 2.35 & 0.33 & 9.00 \\
\hline \multicolumn{5}{|c|}{ POLISHED SURFACE } \\
\hline average per sample & $120.9 \mathrm{HV}$ & 0.51 & 0.16 & 1.78 \\
\hline all measurements & $120.9 \mathrm{HV}$ & 1.31 & 0.29 & 5.13 \\
\hline
\end{tabular}




\section{A. Z. GUŠTIN et al.: THE UNCERTAINTY OF HARDNESS MEASUREMENTS RELATED TO THE MEASUREMENT METHOD ..}

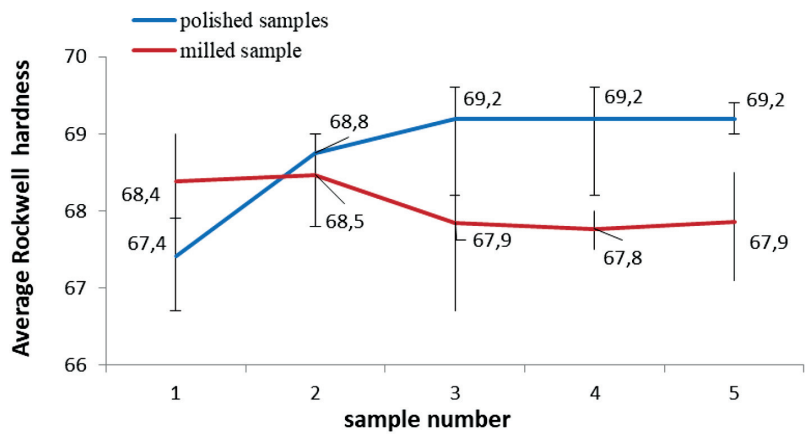

Figure 6: Average Rockwell hardness results obtained on milled and polished specimens

on a single specimen the standard deviation $(s)$ is between $0.17 \%$ and $0.56 \%$, the estimated measurement uncertainty $(u)$ between $0.05 \%$ and $0.18 \%$ and the repeatability $(b)$ between $0.58 \%$ and $2.02 \%$.

Taking into account all 50 individual measurements, the standard deviation $(s)$ is $1.11 \%$, the measurement uncertainty $0.16 \%$ and the repeatability $(b) 4.22 \%$ (Table 3).

According to measurements performed on a single sample a polished surface provides a lower measurement reliability. The standard deviation decreased from $0.64 \%$ to $0.50 \%$, the estimated measurement uncertainty from $0.20 \%$ to $0.16 \%$, and the repeatability from $2.06 \%$ to $1.78 \%$ (Figure 7). However, the situation is the opposite when considering all the measurements performed on 5 samples. In this case the standard deviation being increased to $1.11 \%$, the repeatability to $4.22 \%$ and the

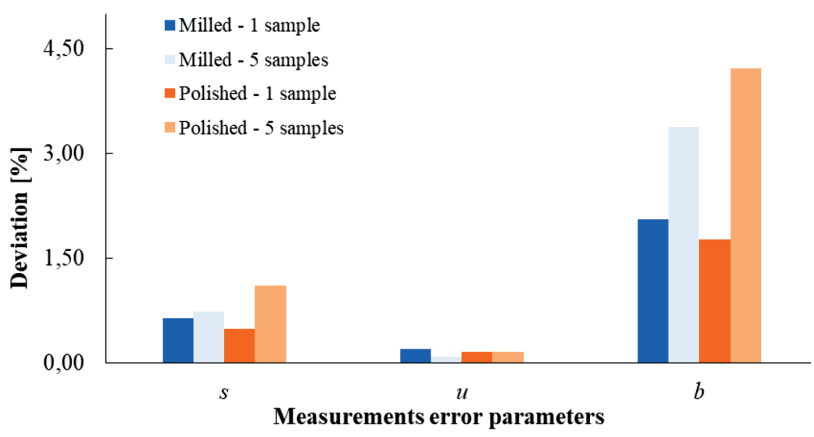

Figure 7: Influence of surface preparation on the measurement error for the Rockwell test method (Table 3)

Table 3: Statistical calculations according to measurements performed on five milled and polished specimens by the Rockwell test

\begin{tabular}{|l|c|c|c|c|}
\hline $\begin{array}{c}\text { Deviation } \\
\text { calculations (\%) }\end{array}$ & $\bar{x}$ & $s$ & $u$ & $b$ \\
\hline \multicolumn{5}{|c|}{ MILLED SURFACE } \\
\hline average per sample & $68.1 \mathrm{HRB}$ & 0.64 & 0.20 & 2.06 \\
\hline all measurements & $68.1 \mathrm{HRB}$ & 0.74 & 0.10 & 3.38 \\
\hline \multicolumn{5}{|c|}{ POLISHED SURFACE } \\
\hline average per sample & $68.8 \mathrm{HRB}$ & 0.50 & 0.16 & 1.78 \\
\hline all measurements & $68.8 \mathrm{HRB}$ & 1.11 & 0.16 & 4.22 \\
\hline
\end{tabular}

estimated measurement uncertainty does not change (Figure 7).

\section{DISCUSSION}

Besides the surface preparation and quality, the number of performed measurements considerably influences the measurement error and uncertainty. The measured results for Brinell, Vickers and Rockwell hardness testing using a different number of measurements are depicted in Figures 8 to $\mathbf{1 0 .}$

According to the Brinell test (Figure 8 and Figure 9) increasing the number of performed measurements from 2 to 10 has only a minor effect on the average value and repeatability, with the differences being less than $1.0 \%$ for the milled and even below $0.2 \%$ for the polished surface. On the other hand, the number of performed measurements has a significant influence on the measurement reliability, including the standard deviation and measurement uncertainty (Figure 9).

If only two HBW measurements are performed on the milled surface, the standard deviation is above $2 \%$, the estimated uncertainty is $1.6 \%$ and repeatability amounts to $2.7 \%$ (Figure 9). To achieve a standard deviation of less than $1 \%$ and a measurement uncertainty of less than $0.5 \%$, it is necessary to carry out 7 to 10 measurements (Figure 9). In the case of the polished surface only three to five measurements are sufficient to obtain a standard deviation lower than $1 \%$ and a measurement uncertainty lower than $0.5 \%$ (Figure 9).

In the case of the Vickers hardness measurement (Figure 10), the influence of the number of performed measurements is even more visible, as well as the influence of surface preparation. On the milled surface 10 measurements are required to achieve a measurement uncertainty of less than $1.5 \%$ and a standard deviation of less than $3.5 \%$, while on the polished surface already three measurements provide a standard deviation below $1.5 \%$ and a measurement uncertainty below $1 \%$ (Fig-

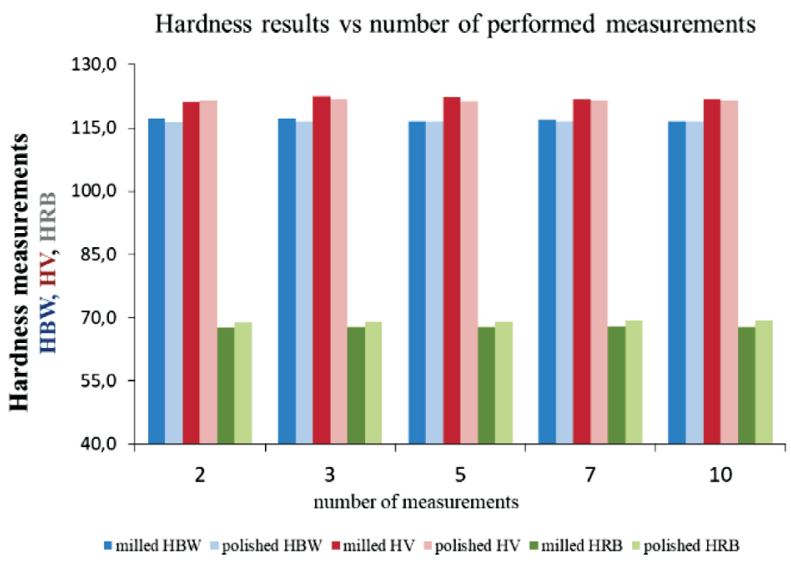

Figure 8: Influence of the number of performed measurements on the average value for Brinell, Vickers and Rockwell hardness test, respectively 
ure 10). By increasing the number of measurements on the polished surface to 7 standard deviation close to $1 \%$ and a measurement uncertainty less than $0.5 \%$ is achieved.

In the case of the Rockwell test method the influence of the number of performed measurements on the measurement reliability is depicted in Figure 11. Similar to the Brinell and Vickers methods the change in average value is minor when increasing the number of measurements from 2 to 10 . The difference is less than $0.5 \%$. Furthermore, already three measurements are sufficient to provide a standard deviation of lower than $1 \%$ (Figure 11) and a measurement uncertainty lower than $0.5 \%$ (Figure 11) if the surface is polished. For the milled
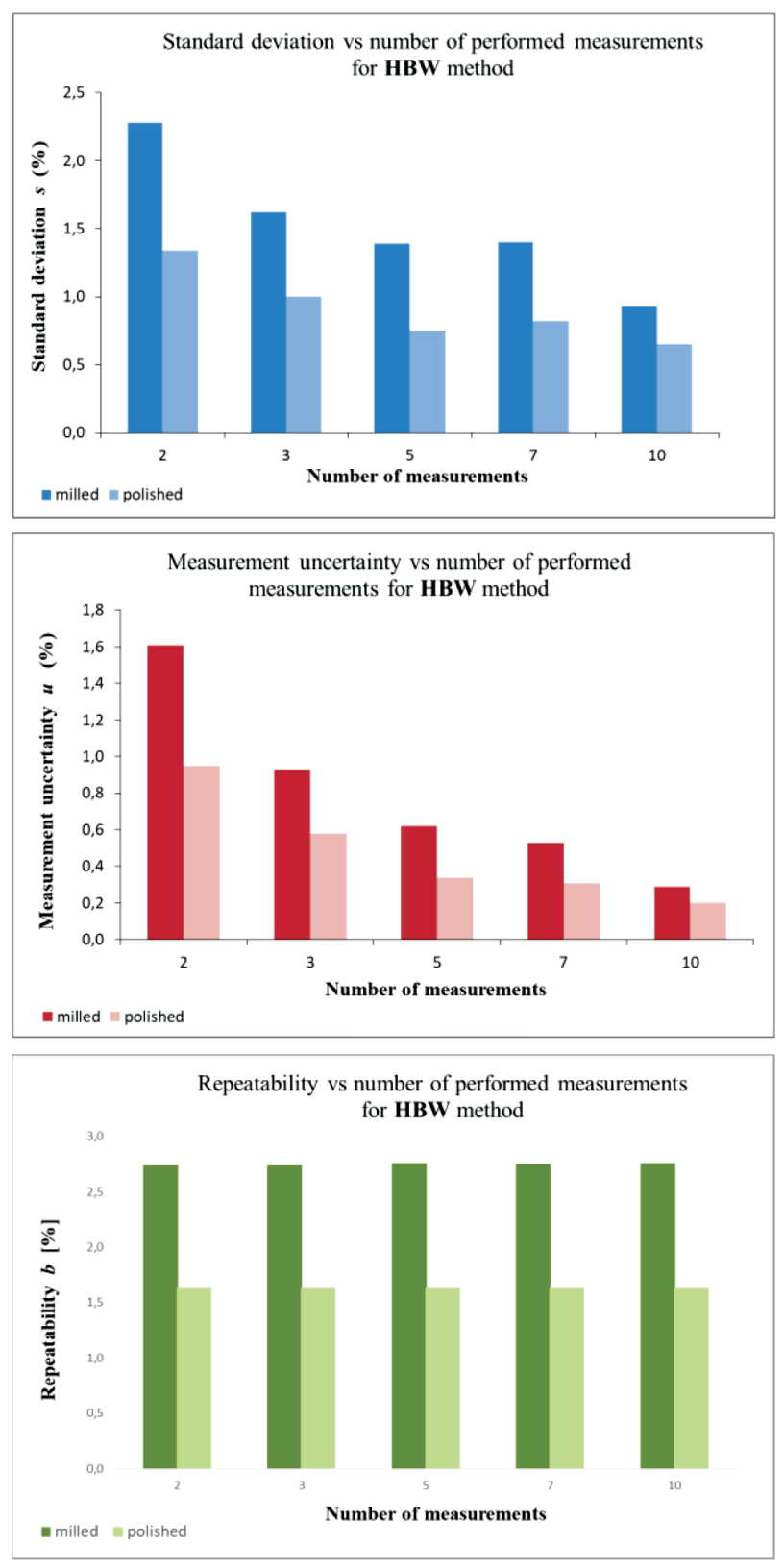

Figure 9: Influence of the number of performed measurements on the measurement reliability for the Brinell test method
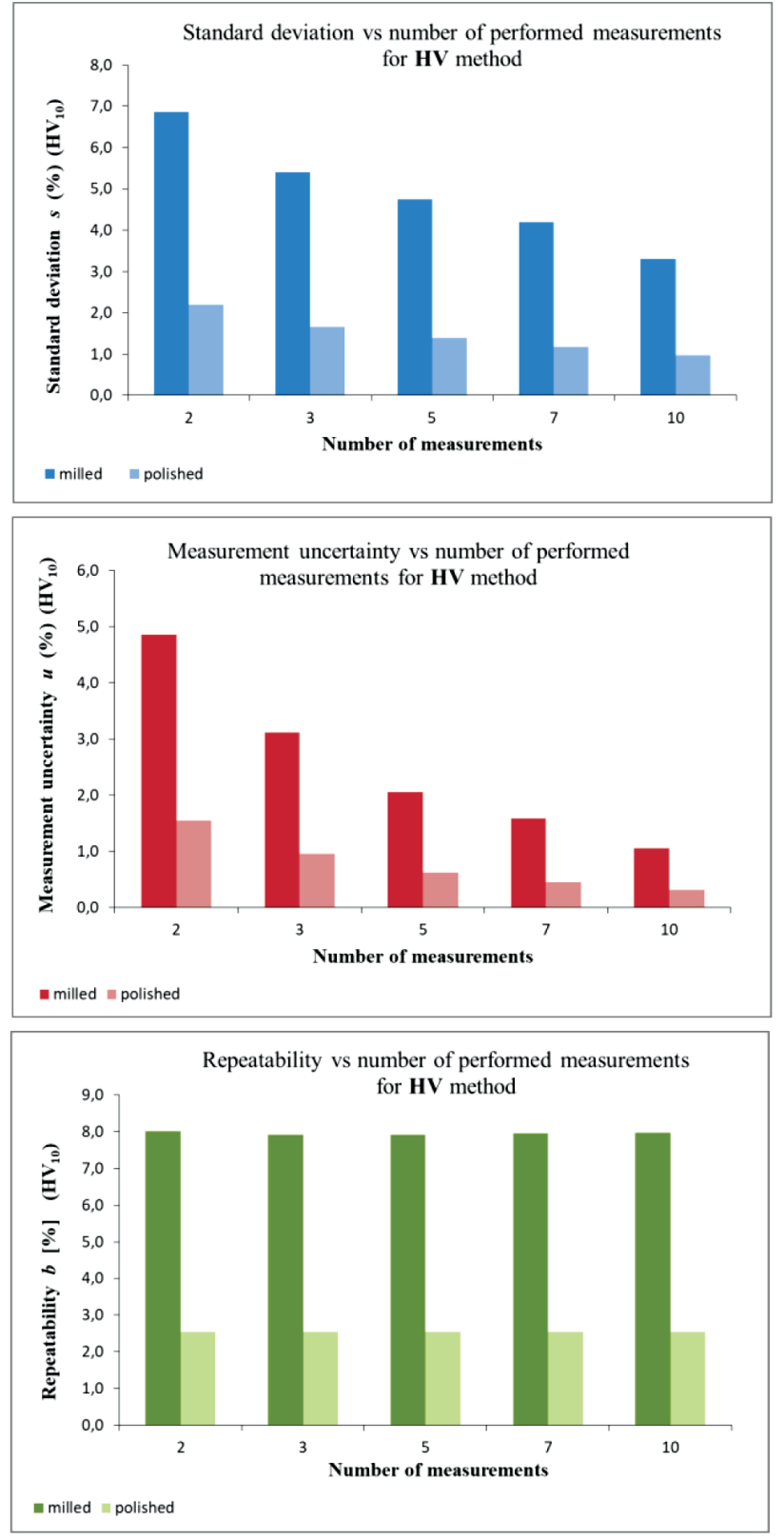

Figure 10: Influence of the number of performed measurements on the measurement reliability for the Vickers test method

surface these values are obtained when performing five measurements. A further increase in the number of performed measurements no longer significantly affects the reliability of the results. A much bigger influence and improvement is obtained with the surface polishing.

An analysis of measurement uncertainty $(u)$, standard deviation $(s)$ and repeatability $(b)$ shows that the highest uncertainty in the hardness measurements performed on Al alloys occurs for the Vickers hardness test, being almost three times higher than the Brinell and Rockwell methods (Figure 12). On the other hand, the best results in terms of measurement reliability are obtained for the Rockwell test, with the measurement uncertainty being between $0.18 \%$ and $0.14 \%$ and for the Brinell from 

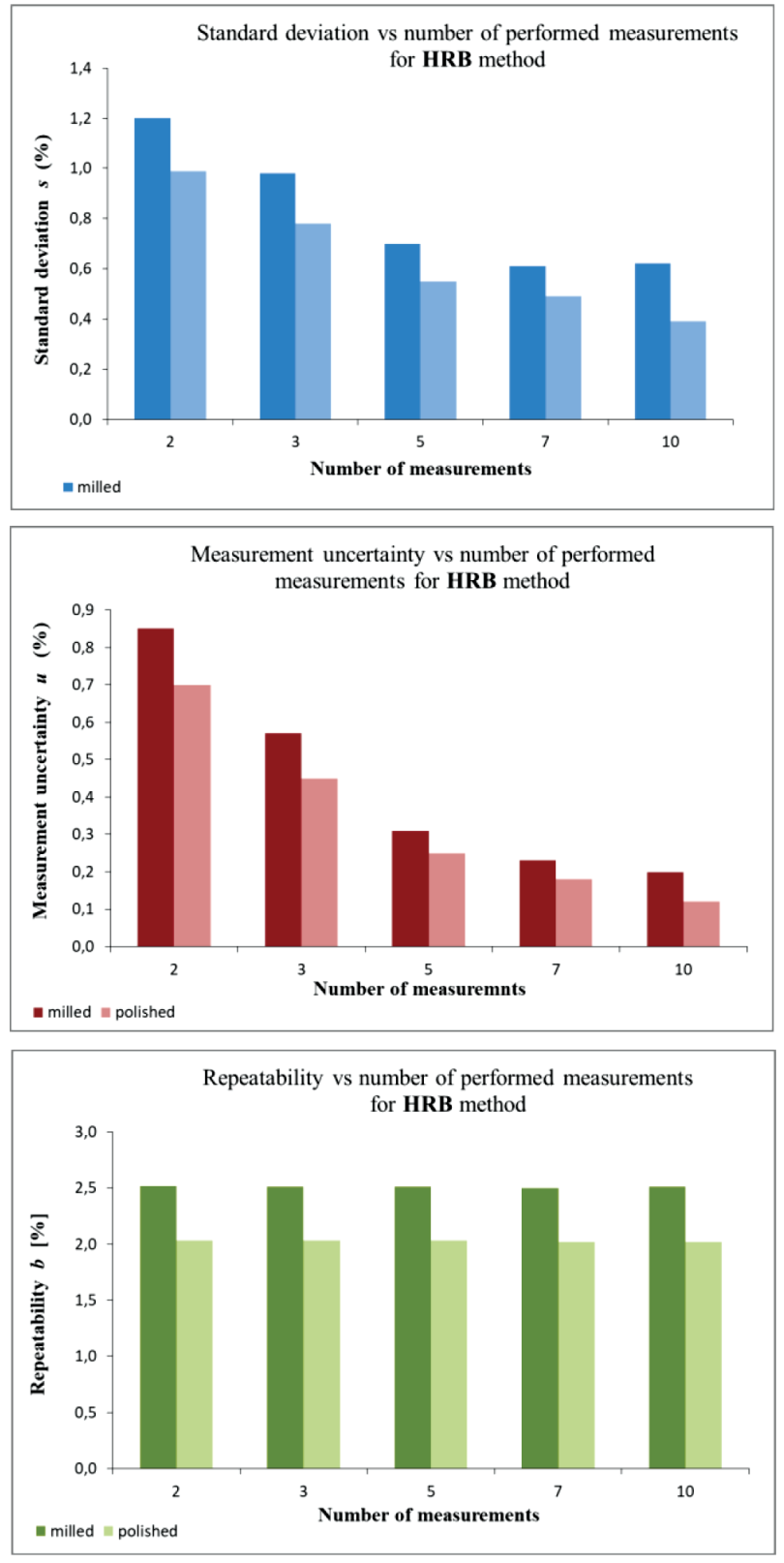

Figure 11: Influence of the number of performed measurements on the measurement reliability for the Rockwell test method

$0.20 \%$ to $0.12 \%$. Looking at different preparations of the surface (milled or polished), again surface polishing has the biggest influence in the case of the Vickers test method, improving the measurement uncertainty by about $75 \%$ (Figure 12). In the case of the Brinell test method the improvement is about $40 \%$ and for Rockwell about $20 \%$.

\section{CONCLUSIONS}

The measurement reliability analysis of different hardness measurement methods applied on an $\mathrm{Al} 2 \mathrm{xxx}$ series aluminium alloy, including the calculation of the average value, measurement uncertainty $(u)$, standard

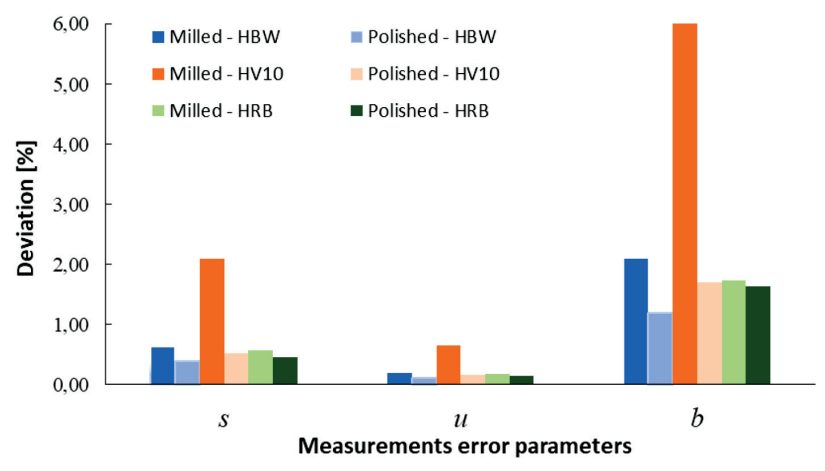

Figure 12: Comparison of measurement reliability for different hardness test methods and surface preparation when applied to $\mathrm{Al}$ alloys

deviation $(s)$ and repeatability $(b)$, has been presented. The results of the analysis can be summarized in the following conclusions:

- Surface polishing has a considerable influence on the measurement uncertainty for Al alloys' hardness measurements. The biggest effect is observed in the case of Vickers hardness measurements, with polished surfaces providing 4-5 times lower measurement uncertainty and deviation.

- Uncertainty in Al alloys hardness measurement is the highest for the Vickers hardness test, almost three times higher than the Brinell and Rockwell measurement methods.

- For the Vickers hardness tests at least 10 measurements on a milled surface have to be performed in order to achieve a measurement uncertainty below $1.5 \%$, while for the polished surface 3-5 measurements are enough. On the other hand, the number of performed measurements has practically no influence on the average hardness value and repeatability.

- To achieve the same measurement uncertainty of $1.5 \%$, at least 5 measurements need to be performed on milled and at least 3 measurements on a polished surface when using the Brinell and Rockwell methods, respectively.

- In general, performing hardness measurements on several samples reduces the measurement uncertainty but emphasizes the material non-homogeneity, especially in combination with polished surfaces.

\section{Acknowledgment}

This research was a part of an interlaboratory proficiency project carried out between industry and the materials testing facility at the Institute of Metals and Technology, which was partly financed by the Slovenian Research Agency (research core funding No. P2-0050) and the company Impol. 


\section{A. Z. GUŠTIN et al.: THE UNCERTAINTY OF HARDNESS MEASUREMENTS RELATED TO THE MEASUREMENT METHOD ...}

\section{REFERENCES}

${ }^{1}$ G. Verdins, D. Kanaska, V. Kleinbergs, Selection of the method of hardness test, $12^{\text {th }}$ International Scientific Conference - Engineering for rural development, Jelgava, Latvia 2013, 217-220

${ }^{2}$ M. S. Bobji, K. Shivakumar, H. Alehossein, V. Venkateshwarlu, S. K. Biswas, Influence of surface roughness on the scatter in hardness measurements - A numerical study, International Journal of Rock Mechanics and Mining Science \& Geomechanics, 36 (1999) 1 , 399-404, doi:10.1016/S0148-9062(99)00009-1

${ }^{3}$ A. M. Hassa, A. S. Al-Bsharat, Influence of burnishing process on surface roughness, hardness, and microstructure of some non-ferrous metals, Wear, 199 (1996) 1, 1-8, doi:10.1016/0043-1648(95)06847-3 ${ }^{4}$ I. Maslenikov, A. Useinov, A. Birykov, V. Reshetov, Reducing the influence of the surface roughness on the hardness measuremen using instrumented indentation test, Materials Science and Engineering, 256 (2017), 1-5, doi:10.1088/1757-899X/256/1/012003
${ }^{5}$ S. R. Low, W. S. Liggett Jr., An empirical approach to determining Rockwell hardness measurement uncertainly, Proceedings of the IMEKO TC3/TC5/TC20 International Conference, 2002

${ }^{6}$ EURAMET, Guidelines on the Estimation of Uncertainty in Hardness Measurements, cg-16/v.01, 2007

${ }^{7}$ ISO 6506-1:2014-Brinell hardness test, Presentation and indication ISO Committee, Geneve

${ }^{8}$ ISO 6507-1:2006-Vickers hardness test, Presentation and indication ISO Committee, Geneve

${ }^{9}$ ISO 6508-1:2015-Rockwell hardness test, Presentation and indication ISO Committee, Geneve

${ }^{10} \mathrm{~S}$. Klysz, J. Lisiecki, Selected problems of measurement uncertainty part I, Technical Sciences, 8 (2008), 1-22, doi:10.2478/v10022-0080018-8 